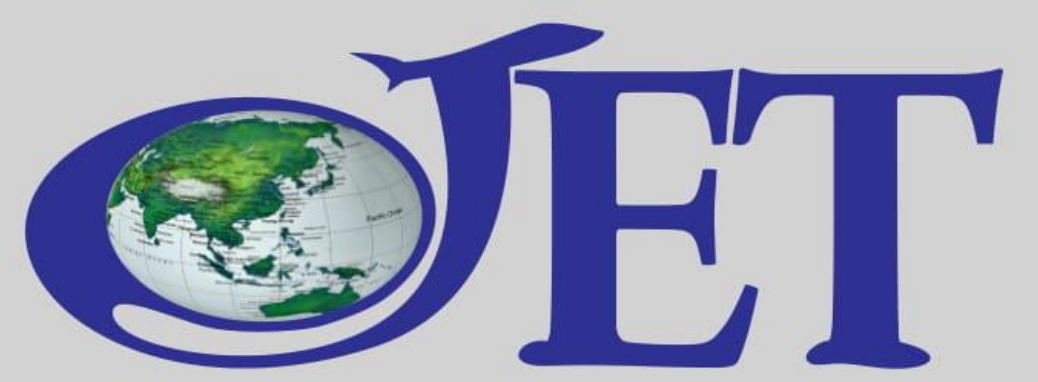

Journal of English Teaching a

ISSN 20809628

triannual

publication

on the study of

English Language Teaching

Volume 4, Number 1, February 2018

\title{
Senior High School Students’ Anxiety towards Language Learning Skills
}

\author{
Hendrikus Male \\ hendrikus.male@uki.ac.id \\ Universitas Kristen Indonesia
}

\begin{abstract}
This study merely aims to investigate Senior High School Students' language anxiety and also to find out what class obtains the most dominant language anxiety. The respondents were administered a set of questionnaire and interview which was adapted from Muhaisen and Al-Haq (2012) The result of data analysis showed that the most dominant of the students' anxiety were found in speaking followed by reading, writing and listening in their language learning process. It is highly recommended that the teachers be more creative in making the class atmosphere to be more fun and relaxing in teaching the language skills so that the students are more encouraged to learn the language.
\end{abstract}

Keywords: language anxiety, senior high school students, language learning process

\section{Introduction}

For Indonesian English is considered a foreign language. According to Kachru (1992, p. 352) Indonesia belongs to the 'expanding circle', meaning that English has no historical or governmental role but it is widely used for communication in that country. Hence, students of English as a Foreign Language (EFL) may undergo a lot of difficulties in learning English language skills. Not only is the language a foreign language but also it is not fully used in their surroundings of everyday life, besides much time consumed and challenge to learn the language. 
In Indonesia High School curriculum, English has become one of the subjects nationally tested. Even though the language skills have been long integrated to one another, it does not guarantee that the students are able to master all the language skills. This may due to the factors that cause the learners fail. As Ghania (2012, p. 1) showed that there are two factors influencing the learners - the internal and external factors. Intelligence, perception, self esteem and learning style belong to internal factor and motivation and cultural social status belong to the external factor. Tharp and Gallimore (1998) argued that in order to be successful in language learning, one should not only have classroom activities but also social interaction, particularly in a community or culture. In addition, senior high school students may easily feel worried when they are exposed to foreign language learning. This links to what Worde (1998) argued that a large number of foreign language learners experience kinds of anxiety in their language learning.

A great number of researches have been conducted by many researchers to investigate the learners' anxiety related to the success in language learning (Horwitz, Horwitz, \& Cope, 1986; MacIntyre \& Gardner, 1991a, 1991b; Bailey, et al. 2000; Cheng, 2001; Brantmeier, 2005). In their studies, they found out that the learners have problems with their anxiety whenever dealing with the language learning. The result also varied from one to another in the sense that some have high degree of anxiety over the other.

Due to the influence of anxiety to the success in language learning may exist, the writer attempted to carry out a similar study and to find out what language skills students experienced the most in terms of anxiety.

\section{Literature Review}

\section{Anxiety}

A few researchers have defined the anxiety in relation to language learning. Haskin (2003) defines anxiety as a feeling of uneasiness, aggravation, self-doubt, lack of confidence, or fear; intricately entwined with self-esteem issues and natural "ego-preserving" worries. Spielberger (in Brown, 2007) stated that anxiety is "the subjective feeling of tension,

apprehension, nervousness, and worry associated with an arousal of the automatic nervous system".

Horwitz, Horwitz, and Cope (1986) state as complicated differences of self-perceptions, beliefs, feelings and behaviors related to classroom language learning that occur due to the 
uniqueness of the language learning process.MacIntyreand Gardner (1994) focused more on the feeling of tension andapprehension specifically in second-language contexts, including speaking, listening, reading, and writing.

Additionally, Horwitz et al. (1986) identify three types of anxiety related to foreign language anxieties: communication apprehension, test anxiety, andfear of negative evaluation. Communication apprehension refers to the fear of communicating with other people. It is atype of shyness characterized by fear or anxiety about communicating with people. Test anxiety is about the fear ofexams, quizzes, and other assignments used to evaluate students' performance. The fear of negative evaluation refers tothe apprehension about others' evaluation.

Researchers have conducted a number of studies dealing with anxiety in the context of foreign language classroom - what so-called Foreign Language Classroom Anxiety (FLCA) (Horwitz, et al. (1991); MacIntyre and Gardner (1991a); Horwitz, Horwitz\& Cope (1986). The researchers argued that FLCA have a complex issue that needs to be considered in the process of learning the language. Another scholar, Zheng, (2008) has showed that learners learning the language may have "traumatic experience" due to their anxiety.Anxiety can also be caused by personality differences, as Myers and Myers (1995, p. 77)identified the learners' personality type, i.e., being introvert and extrovert as can be seen in Table 1.

Table 1:

Differences between Extraversion and Introversion

\begin{tabular}{ll}
\hline Extraversion & Introversion \\
\hline $\begin{array}{l}\text { 1. Prefer the outer world of people } \\
\text { and thing to reflection. }\end{array}$ & $\begin{array}{l}\text { 1. Prefer reflection and the inner } \\
\text { world of action. }\end{array}$ \\
$\begin{array}{ll}\text { 2. Active. } & \text { 2. Prefer writing to talking. } \\
\text { 3. Gain energy from others. } & \text { 3. May enjoy social contact but } \\
\text { 4. Want to experience things in order } & \text { need to recover from it. } \\
\text { to understand them. } & \text { 4. Want to understand something } \\
\text { 5. Work by trial and variety. } & \text { before trying it. } \\
& \text { 5. Like a quiet space to work in. }\end{array}$
\end{tabular}




\section{Factors Affecting the Language Learning Anxiety}

There can be a great deal of factors influencing language learning that result in negative impacts. Some scholars such as Cooke, Bewick, Barkham, Bradley, \& Audin (2006) stated that when learners have anxiety, they tend to change their behaviour such as unwilling to study, difficult in concetrating and etc. This isin line with Horowitz et al, (1986) stating there are three aspects of anxiety offoreign languagelearning, i.e., apprehension of verbal communication, testanxiety, and apprehension of negative evaluation. Learners should know their own ways of approaches in order to work well with their language skills specifically writing. Pritchard (2009) suggested that it is helpful for learners if they areaware of their own particular approach of learning, and take moreopportunities to improve their way of learning.

In accordance with all the previous explanations that anxiety towards foreign language learning can be understood since the language skill is one of the most difficult one. In addition, the specific purpose of the research is to find out the students' degree of foreign language anxiety. The research question is as follow: "How is the students' foreign language anxiety?"

\section{Methodology}

This research was a descriptive research aiming to describe the students' degree of foreign language anxiety and using explanatory mixed method design, in which according to Creswell (2003), it enables the researchers to gather qualitative input, to explain, and extend the quantitative results where its purpose is to obtain a comprehensive insight of the study. This study was conducted in November 2017 at SMA Pusaka 1, Jakarta Timur.

The data were collected through questionnaire and interview to respondents. A set of questionnaire adapted and modified from Muhaisen and Al-Haq (2012). It consisted of 50 items (10 items of listening skill, 14 items of Speaking skill, 13 items reading skill, and 13 items writing skill was used). The questionnaire was also divided into four main categories - Listening, Speaking, Reading, and Writing. To get the interview data, a set of interview was administered to a number of students who were randomly taken from each batch.. The questions of interview were taken from the statements in the questionnaire. The data collected then used descriptive statistic. 


\section{Findings and Discussions}

\section{Findings}

\section{Data Demography}

The data demography of the study was merely focused on gender, age, and batch. Only few participants were male. The participants were dominated by the female participants with varied age from 15-17 years old. In this study the participants consisted of three batches 2015, 2016, and 2017 with the total number of the respondents is 85 .

\section{Students' Anxiety}

The following is the distribution of the Respondents' Overall Anxiety found in this study as can be seen in Table 2 .

Table 2:

Respondents' Overall Frequency of Anxiety

\begin{tabular}{ccccc}
\hline \multirow{2}{*}{ No } & & \multicolumn{3}{c}{ Respondents (N=85) } \\
\cline { 3 - 5 }$\cdot$ & Anxiety of Language & Agree & Undecided & Disagree \\
\cline { 2 - 5 } & Skills & $\mathrm{F}$ & $\mathrm{f}$ & $\mathrm{f}$ \\
\hline 1 & Listening & 420 & 254 & 91 \\
\hline 2 & Speaking & 601 & 481 & 193 \\
\hline 3 & Reading & 499 & 389 & 132 \\
\hline 4 & Writing & 462 & 455 & 188 \\
\hline
\end{tabular}

Table 2 shows that the majority of the respondents' anxiety was found in speaking skill. It can be seen in the highest frequency of instances in the study i.e., 601 instances found in Agree followed by, Undecided (481 instances), and Disagree (193 instances). The Reading skill in the second rank with the highest frequency is found in Agree (499 instances), followed by Undecided (389 instances), and Disagree (132 instances). The third rank is Writing skill with the total frequency was found in Undecided (462 instances), followed by Agree (455 instances), and Disagree (188 instances).The last frequency of respondents' anxiety was in Listening skill ranged from the highest to the lowest one Agree (420 instances), followed by Undecided (254 instances), and Disagree (91 instances). 


\section{Discussion}

The following are the discussions of the research classified based on the most dominant order of occurrences ranged from the highest to the lowest rank. The findings showed that the most dominant anxiety is Speaking, followed by Reading, Writing and the last is Listening. To support the data, the interview result is then included in the study.

Since the discussion covers the most anxiety of the respondents' language skills i.e., the Speaking, Reading, Writing, and Listening. The first anxiety of language skills found was Speaking skill (see Table 3).

Table 3:

Respondents' Perceptions of Anxiety in Speaking Skill Learning

\begin{tabular}{|c|c|c|c|c|}
\hline \multirow{3}{*}{ No. } & \multirow{3}{*}{ Speaking Skill } & \multicolumn{3}{|c|}{ Respondents $(\mathrm{N}=85)$} \\
\hline & & Agree & Undecided & $\begin{array}{c}\text { Disagre } \\
\mathrm{e}\end{array}$ \\
\hline & & $\mathrm{f}(\%)$ & $\mathrm{f}(\%)$ & $\mathrm{f}(\%)$ \\
\hline 1 & $\begin{array}{l}\text { I feel worried when I have to speak } \\
\text { to others in English. }\end{array}$ & $\begin{array}{c}40 \\
(47.10)\end{array}$ & $\begin{array}{c}41 \\
(48.20)\end{array}$ & $\begin{array}{c}4 \\
(4.70)\end{array}$ \\
\hline 2 & $\begin{array}{l}\text { I am worried about expressing } \\
\text { myself clearly when I am talking in } \\
\text { English. }\end{array}$ & $\begin{array}{c}38 \\
(44.70) \\
\end{array}$ & $\begin{array}{c}41 \\
(48.20) \\
\end{array}$ & $\begin{array}{c}6 \\
(7.10) \\
\end{array}$ \\
\hline 3 & $\begin{array}{l}\text { I feel anxious when I have to make a } \\
\text { presentation in English. }\end{array}$ & $\begin{array}{c}36 \\
(42.40)\end{array}$ & $\begin{array}{c}38 \\
(44.70)\end{array}$ & $\begin{array}{c}11 \\
(13.00)\end{array}$ \\
\hline 4 & $\begin{array}{l}\text { I do not care if my classmates laugh } \\
\text { at my English language when I speak } \\
\text { in class. }\end{array}$ & $\begin{array}{c}47 \\
(55.30) \\
\end{array}$ & $\begin{array}{c}29 \\
(34.10) \\
\end{array}$ & $\begin{array}{c}9 \\
(10.60) \\
\end{array}$ \\
\hline 5 & I feel anxious about oral tests. & $\begin{array}{c}51 \\
(60.00) \\
\end{array}$ & $\begin{array}{c}20 \\
(23.50) \\
\end{array}$ & $\begin{array}{c}14 \\
(16.50) \\
\end{array}$ \\
\hline 6 & $\begin{array}{l}\text { I feel anxious when I have to speak } \\
\text { to my teacher in English. }\end{array}$ & $\begin{array}{c}45 \\
(53.00) \\
\end{array}$ & $\begin{array}{c}28 \\
(32.90) \\
\end{array}$ & $\begin{array}{c}12 \\
(14.10) \\
\end{array}$ \\
\hline 7 & $\begin{array}{l}\text { I am worried that others will laugh at } \\
\text { my English. }\end{array}$ & $\begin{array}{c}39 \\
(45.90)\end{array}$ & $\begin{array}{c}26 \\
(30.60)\end{array}$ & $\begin{array}{c}20 \\
(23.50)\end{array}$ \\
\hline 8 & $\begin{array}{l}\text { I feel bashful when I speak in } \\
\text { English in front of the class. }\end{array}$ & $\begin{array}{c}32 \\
(37.60)\end{array}$ & $\begin{array}{c}38 \\
(44.70)\end{array}$ & $\begin{array}{c}15 \\
(17.70)\end{array}$ \\
\hline 9 & $\begin{array}{l}\text { Oral tasks make me anxious more } \\
\text { than other tasks. }\end{array}$ & $\begin{array}{c}42 \\
(49.40)\end{array}$ & $\begin{array}{c}30 \\
(35.30)\end{array}$ & $\begin{array}{c}13 \\
(15.3)\end{array}$ \\
\hline 10 & $\begin{array}{l}\text { I do not like to be corrected by my } \\
\text { teacher in front of my classmates. }\end{array}$ & $\begin{array}{c}44 \\
(51.80) \\
\end{array}$ & $\begin{array}{c}34 \\
(40.00)\end{array}$ & $\begin{array}{c}7 \\
(8.20) \\
\end{array}$ \\
\hline 11 & $\begin{array}{l}\text { I feel worried about the possibility } \\
\text { that the teacher may ask me a } \\
\text { question. }\end{array}$ & $\begin{array}{c}29 \\
(34.10) \\
\end{array}$ & $\begin{array}{c}24 \\
(28.20) \\
\end{array}$ & $\begin{array}{c}32 \\
(36.60) \\
\end{array}$ \\
\hline
\end{tabular}




\begin{tabular}{llccc}
\hline \multirow{2}{*}{12} & $\begin{array}{l}\text { I get embarrassed when I have to } \\
\text { answer my teacher's questions } \\
\text { orally. }\end{array}$ & $\begin{array}{c}51 \\
(60.00)\end{array}$ & $\begin{array}{c}28 \\
(33.00)\end{array}$ & $\begin{array}{c}6 \\
(7.00)\end{array}$ \\
\hline \multirow{2}{*}{13} & $\begin{array}{l}\text { I do not feel anxious when I speak to } \\
\text { my classmates in English. }\end{array}$ & $\begin{array}{c}31 \\
(36.50)\end{array}$ & $\begin{array}{c}34 \\
(40.00)\end{array}$ & $\begin{array}{c}20 \\
(23.50)\end{array}$ \\
\hline \multirow{2}{*}{14} & I feel better about speaking in & 39 & 33 & 13 \\
& English in a small - sized class. & $(45.90)$ & $(38.80)$ & $(15.30)$ \\
\hline \multirow{2}{*}{15} & I get embarrassed when I have to & 37 & 37 & 11 \\
& answer my teacher's questions & $(43.50)$ & $(43.50)$ & $(13.00)$ \\
\hline & Total of Frequency & 601 & 481 & 193 \\
\hline
\end{tabular}

Table 3 shows that the highest rank of language skills of anxiety was in Speaking. It is clearly seen in the total number of occurrences: 601 instances were found in Agree, followed by 418 instances were found in Undecided. Next, 193 instances were found in Disagree. The result also indicates that the respondents' highest frequency of anxiety were found in the statements\#5 and 12, 51 (60.00\%), expressing their worry having oral text and answering their teachers' questions. The data were also supported by the respondents' interview result when asked whether they felt worried to speak. A number of respondents agreed that they were anxious. A respondent interviewed (R2) responded, "Yes, I'm worried to speak to my teacher because I have many mistakes." Another interviewee (R5) stated, "Yes, my speaking is bad and I am worried to speak too."

It is obvious that the highest degree of anxiety experienced by the students found in this study is in Speaking class. The finding did not confirm highly the study conducted by Muhaisen and Al-Haq (2012), revealing the learners were not much anxious on speaking, but less anxious and categorized as moderate, meaning that the students had little worries on speaking.

In Reading skill the students' degree of anxiety is as shown in Table 4.

Table 4:

Respondents' Perceptions of Anxiety in Reading Skill Learning

\begin{tabular}{clccc}
\hline \multirow{2}{*}{ No. } & \multirow{2}{*}{ Reading Skill } & \multicolumn{3}{c}{ Respondents (N=71) } \\
\cline { 3 - 4 } & & Agree & Undecided & Disagree \\
\cline { 3 - 4 } & & $\mathrm{f}(\%)$ & $\mathrm{f}(\%)$ & $\mathrm{f}(\%)$ \\
\hline 1 & I feel comfortable when reading short & 57 & 22 & 6 \\
& texts activities. & $(67.10)$ & $(25.90)$ & $(7.10)$ \\
\hline 2 & I feel comfortable when reading about & 42 & 33 & 10 \\
& interesting topics. & $(49.40)$ & $(38.80)$ & $(11.80)$ \\
\hline 3 & I feel anxious about misinterpreting a & 38 & 37 & 10 \\
\hline
\end{tabular}




\begin{tabular}{|c|c|c|c|c|}
\hline & written text. & $(44.70)$ & $(43.50)$ & $(11.80)$ \\
\hline 4 & $\begin{array}{l}\text { I get frustrated when I do not } \\
\text { understand the main idea of what I } \\
\text { read. }\end{array}$ & $\begin{array}{c}43 \\
(50.60) \\
\end{array}$ & $\begin{array}{c}33 \\
(38.80) \\
\end{array}$ & $\begin{array}{c}9 \\
(10.60)\end{array}$ \\
\hline 5 & $\begin{array}{l}\text { I feel anxious about un familiar } \\
\text { grammatical structures when reading }\end{array}$ & $\begin{array}{c}41 \\
(48.20)\end{array}$ & $\begin{array}{c}29 \\
(34.10)\end{array}$ & $\begin{array}{c}15 \\
17.60)\end{array}$ \\
\hline 6 & $\begin{array}{l}\text { I feel anxious about not understanding } \\
\text { the meaning of every word. }\end{array}$ & $\begin{array}{c}31 \\
(36.50)\end{array}$ & $\begin{array}{c}34 \\
(40.00)\end{array}$ & $\begin{array}{c}20 \\
(23.50)\end{array}$ \\
\hline 7 & $\begin{array}{l}\text { I become anxious when I have to read } \\
\text { English loud in class. }\end{array}$ & $\begin{array}{c}45 \\
(52.90)\end{array}$ & $\begin{array}{c}34 \\
(40.00)\end{array}$ & $\begin{array}{c}6 \\
(7.10) \\
\end{array}$ \\
\hline 8 & $\begin{array}{l}\text { I become anxious when I have to } \\
\text { answer questions in class about what I } \\
\text { read. }\end{array}$ & $\begin{array}{c}43 \\
(50.60) \\
\end{array}$ & $\begin{array}{c}30 \\
(35.30) \\
\end{array}$ & $\begin{array}{c}12 \\
(14.10) \\
\end{array}$ \\
\hline 9 & $\begin{array}{l}\text { I feel worried to see a whole page of } \\
\text { English words in front of my eyes. }\end{array}$ & $\begin{array}{c}36 \\
(42.40)\end{array}$ & $\begin{array}{c}32 \\
(37.60)\end{array}$ & $\begin{array}{c}17 \\
(20.00)\end{array}$ \\
\hline 10 & $\begin{array}{l}\text { I feel worried about the teacher asking } \\
\text { me questions after skimming reading } \\
\text { tasks. }\end{array}$ & $\begin{array}{c}42 \\
(49.40) \\
\end{array}$ & $\begin{array}{c}34 \\
(40.00) \\
\end{array}$ & $\begin{array}{c}9 \\
(10.60)\end{array}$ \\
\hline 11 & $\begin{array}{l}\text { I become anxious when I have to } \\
\text { answer multiple choice questions } \\
\text { about what I read in English. }\end{array}$ & $\begin{array}{c}46 \\
(54.10) \\
\end{array}$ & $\begin{array}{c}31 \\
(36.50)\end{array}$ & $\begin{array}{c}8 \\
(9.41) \\
\end{array}$ \\
\hline 12 & $\begin{array}{l}\text { I get scared when I have to read } \\
\text { lengthy texts in English as a home }\end{array}$ & $\begin{array}{c}35 \\
(41.20) \\
\end{array}$ & $\begin{array}{c}40 \\
(47.10) \\
\end{array}$ & $\begin{array}{c}10 \\
(11.80) \\
\end{array}$ \\
\hline & Total of frequency & 499 & 389 & 132 \\
\hline
\end{tabular}

Table 4 indicates that the second rank anxiety in language skill learning is Reading. It can be seen through the responses on the questionnaire statements as: Agree, 499 occurrences, followed by 389 instances Undecided, and the last, it was found in Disagree 132 instances. Table 4 also shows the highest item of Reading language skill experienced by the students was 57 $(67.10 \%)$ 'I feel comfortable when reading short texts activities.' And the lowest was found in item number 6, 31 (36.50\%) 'I feel anxious about not understanding the meaning of every word."

The data were also supported by the respondents' responses to the interview when asked whether or not they feel worried to read. A number of the respondents confessed that they felt worried to read.(R5) said, "Yes, I am afraid if I read differently. "Another interviewee (R8) stated similar response, "Yes, I have difficulty to read."

When the respondents were asked whether they felt more comfortable reading short or longer text, most of them agreed to have short rather than long text. (R9) admitted, "I like 
reading short text because it is easy." (R12) said, "Short text, I can understand it." In short, the finding related to the students' anxiety when assigned to read is in line with the Muhaisen's and Al-Haq's (2012) study result. Their study revealed that the second degree of the learners' anxiety in reading skill was moderate. The next discussion deals with the respondents writing skill anxiety as can be seen in Table 5.

Table 5:

Respondents' Perceptions of Anxiety in Writing Skill Learning

\begin{tabular}{|c|c|c|c|c|}
\hline \multirow{3}{*}{ No. } & \multirow{3}{*}{ Writing Skill } & \multicolumn{3}{|c|}{ Respondents $(\mathrm{N}=71)$} \\
\hline & & Agree & Undecided & Disagree \\
\hline & & $\mathrm{f}(\%)$ & $\mathrm{f}(\%)$ & $\mathrm{f}(\%)$ \\
\hline 1 & $\begin{array}{l}\text { I feel better if I have prepared for the } \\
\text { writing topic before class. }\end{array}$ & $\begin{array}{c}54 \\
(63.50)\end{array}$ & $\begin{array}{c}24 \\
(28.20)\end{array}$ & $\begin{array}{c}7 \\
(8.24) \\
\end{array}$ \\
\hline 2 & $\begin{array}{l}\text { Interesting topics make me feel } \\
\text { better in writing tasks. }\end{array}$ & $\begin{array}{c}42 \\
(49.40)\end{array}$ & $\begin{array}{c}25 \\
(29.40)\end{array}$ & $\begin{array}{c}18 \\
(21.20)\end{array}$ \\
\hline 3 & $\begin{array}{l}\text { I do not care about what others may } \\
\text { think about my writing. }\end{array}$ & $\begin{array}{c}42 \\
(49.40)\end{array}$ & $\begin{array}{c}35 \\
(41.20)\end{array}$ & $\begin{array}{c}8 \\
(9.41)\end{array}$ \\
\hline 4 & $\begin{array}{l}\text { I feel comfortable when I am asked } \\
\text { to write about topics that I am } \\
\text { familiar with. }\end{array}$ & $\begin{array}{c}40 \\
(47.10) \\
\end{array}$ & $\begin{array}{c}34 \\
(40.00) \\
\end{array}$ & $\begin{array}{c}11 \\
(12.90)\end{array}$ \\
\hline 5 & $\begin{array}{l}\text { I start to worry when I know } \\
\text { I will be graded in writing. }\end{array}$ & $\begin{array}{c}34 \\
(40.00)\end{array}$ & $\begin{array}{c}36 \\
(42.40)\end{array}$ & $\begin{array}{c}15 \\
(17.60)\end{array}$ \\
\hline 6 & $\begin{array}{l}\text { I feel frustrated if I fail to organize } \\
\text { my ideas coherently. }\end{array}$ & $\begin{array}{c}31 \\
(36.50) \\
\end{array}$ & $\begin{array}{c}46 \\
(54.10) \\
\end{array}$ & $\begin{array}{c}8 \\
(9.41) \\
\end{array}$ \\
\hline 7 & $\begin{array}{l}\text { I worry about how to organize my } \\
\text { thoughts and ideas in an English } \\
\text { composition. }\end{array}$ & $\begin{array}{c}35 \\
(41.20) \\
\end{array}$ & $\begin{array}{c}31 \\
(36.50) \\
\end{array}$ & $\begin{array}{c}19 \\
(22.40) \\
\end{array}$ \\
\hline 8 & $\begin{array}{l}\text { I worry about writing even if my } \\
\text { writing will not be graded. }\end{array}$ & $\begin{array}{c}33 \\
(38.80) \\
\end{array}$ & $\begin{array}{c}43 \\
(50.60) \\
\end{array}$ & $\begin{array}{c}9 \\
(10.60) \\
\end{array}$ \\
\hline 9 & $\begin{array}{l}\text { I worry about finding the appropriate } \\
\text { expression to write a composition. }\end{array}$ & $\begin{array}{c}16 \\
(18.80) \\
\end{array}$ & $\begin{array}{c}30 \\
(50.60) \\
\end{array}$ & $\begin{array}{c}39 \\
(45.90) \\
\end{array}$ \\
\hline 10 & $\begin{array}{l}\text { I am worried about being asked to } \\
\text { write a composition. }\end{array}$ & $\begin{array}{c}46 \\
(54.10)\end{array}$ & $\begin{array}{c}36 \\
(42.40) \\
\end{array}$ & $\begin{array}{c}3 \\
(3.53)\end{array}$ \\
\hline 11 & $\begin{array}{l}\text { I am worried about what others may } \\
\text { think about my writing. }\end{array}$ & $\begin{array}{c}33 \\
(38.80) \\
\end{array}$ & $\begin{array}{c}39 \\
(45.90) \\
\end{array}$ & $\begin{array}{c}13 \\
(15.30) \\
\end{array}$ \\
\hline 12 & $\begin{array}{l}\text { I am afraid to ask my } \\
\text { teacher for help in writing. }\end{array}$ & $\begin{array}{c}28 \\
(32.90) \\
\end{array}$ & $\begin{array}{c}42 \\
(49.40) \\
\end{array}$ & $\begin{array}{c}15 \\
(17.60)\end{array}$ \\
\hline 13 & $\begin{array}{l}\text { I feel bashful to ask my classmate for } \\
\text { help. }\end{array}$ & $\begin{array}{c}28 \\
(32.90) \\
\end{array}$ & $\begin{array}{c}34 \\
(47.10) \\
\end{array}$ & $\begin{array}{c}23 \\
(20.00) \\
\end{array}$ \\
\hline & Total of frequency & 462 & 455 & 188 \\
\hline
\end{tabular}


Table 5 indicates the third rank of the respondents' anxiety in language learning is in writing skill. It is obviously stated that among 13 items of writing skills statements, 462 instances were found in agree, followed by 455 undecided, and188 frequencies found in disagree. Table 5 also shows the highest frequency of anxiety in writing skill anxiety experienced by the students was 54 (63.50\%), 'I feel better if I have prepared for the writing topic before class.' And the lowest item was 16 (18.80\%), 'I worry about finding the appropriate expression to write a composition. 'meaning that they are worried if they are required to find out appropriate expression when composing.

The data were supported by the respondents' interview analysis result. When the respondents were asked about whether they felt worried to write, a number of interviewees said,'Yes I feel worried. Because, I am afraid of mistakes.”(R4). (R11) said,'Yes, I worry to write because I don't have many vocabularies."

The result shows that most of the respondents were also worried about their writing skill and they seemed to prefer preparing their material in advance before the class as their own way to reduce their anxiety.

Analysis of the respondents' anxiety related to listening learning resulted in variation. The results are presented in Table 6. 
Table 6:

Respondents' Perceptions of Anxiety in Listening Skill Learning

\begin{tabular}{|c|c|c|c|c|}
\hline \multirow[b]{2}{*}{ No } & \multirow{3}{*}{ Listening Skill } & \multicolumn{3}{|c|}{ Respondents $(\mathrm{N}=71)$} \\
\hline & & Agree & Undecided & Disagree \\
\hline • & & $\mathrm{f}(\%)$ & $\mathrm{f}(\%)$ & $\mathrm{f}(\%)$ \\
\hline 1 & $\begin{array}{l}\text { I am worried when I do not } \\
\text { understand what the teacher is } \\
\text { saying in English class. }\end{array}$ & $\begin{array}{c}56 \\
(65.90) \\
\end{array}$ & $\begin{array}{c}26 \\
(30.60) \\
\end{array}$ & $\begin{array}{c}3 \\
(3.50)\end{array}$ \\
\hline 2 & $\begin{array}{l}\text { I am worried when I do not } \\
\text { understand every word I hear. }\end{array}$ & $\begin{array}{c}54 \\
(63.50) \\
\end{array}$ & $\begin{array}{c}26 \\
(30.60)\end{array}$ & $\begin{array}{c}5 \\
(5.90)\end{array}$ \\
\hline 3 & $\begin{array}{l}\text { I feel anxious when I do not } \\
\text { understand English spoken with an } \\
\text { unfamiliar accent. }\end{array}$ & $\begin{array}{c}47 \\
(55.30) \\
\end{array}$ & $\begin{array}{c}31 \\
(36.50) \\
\end{array}$ & $\begin{array}{c}7 \\
(8.20) \\
\end{array}$ \\
\hline 4 & $\begin{array}{l}\text { I feel anxious when someone speaks } \\
\text { to me quickly. }\end{array}$ & $\begin{array}{c}49 \\
(57.60) \\
\end{array}$ & $\begin{array}{c}27 \\
(31.80) \\
\end{array}$ & $\begin{array}{c}9 \\
(11.00) \\
\end{array}$ \\
\hline 5 & I feel anxious about listening tasks. & $\begin{array}{c}39 \\
(4590)\end{array}$ & $\begin{array}{c}28 \\
(3290)\end{array}$ & $\begin{array}{c}18 \\
(21 \cap 0)\end{array}$ \\
\hline 6 & $\begin{array}{l}\text { I feel anxious when listening to } \\
\text { intricate topics. }\end{array}$ & $\begin{array}{c}45 \\
(52.90)\end{array}$ & $\begin{array}{c}31 \\
(36.50)\end{array}$ & $\begin{array}{c}9 \\
(11.00)\end{array}$ \\
\hline 7 & $\begin{array}{l}\text { I feel anxious when I listen to a long } \\
\text { conversation. }\end{array}$ & $\begin{array}{c}46 \\
(54.10) \\
\end{array}$ & $\begin{array}{c}27 \\
(31.80) \\
\end{array}$ & $\begin{array}{c}12 \\
(14.00) \\
\end{array}$ \\
\hline 8 & $\begin{array}{l}\text { I feel anxious when someone speaks } \\
\text { to me about a topic I am not familiar } \\
\text { with. }\end{array}$ & $\begin{array}{c}45 \\
(52.90) \\
\end{array}$ & $\begin{array}{c}29 \\
(34.10) \\
\end{array}$ & $\begin{array}{c}11 \\
(13.00) \\
\end{array}$ \\
\hline 9 & $\begin{array}{l}\text { I feel anxious when I have to listen } \\
\text { to a speech without any visual aids } \\
\text { (e.g. drawings, pictures, notes...etc). }\end{array}$ & $\begin{array}{c}39 \\
(45.90)\end{array}$ & $\begin{array}{c}29 \\
(34.10)\end{array}$ & $\begin{array}{c}17 \\
(20.00)\end{array}$ \\
\hline 10 & $\begin{array}{l}\text { Listening to short dialogues/ } \\
\text { conversations enables me to } \\
\text { remember what I hear easily. }\end{array}$ & $\begin{array}{c}56 \\
(65.90) \\
\end{array}$ & $\begin{array}{c}26 \\
(30.60) \\
\end{array}$ & $\begin{array}{c}3 \\
(3.50) \\
\end{array}$ \\
\hline & Total of Frequency & 420 & 254 & 91 \\
\hline
\end{tabular}

Table 6 describes the last rank of the respondents' anxiety when doing with listening skill. It is clearly seen in the total of occurrences of each frequency,420 instances were found in Agree, followed by 254 instances in Undecided. Ninety nine instances were found in Disagree. The result also indicates that the highest frequency of respondents anxiety when involved in listening skill is in the statements\#1 and 10, 56 (65.90\%), i.e., "I am worried when I do not understand what the teacher is saying in English class and Listening to short dialogues/ conversations enables me to remember what I hear easily, meaning that most of them agreed or 
had no worries if they had short dialogues/conversation and they also felt worried when they did not understand what the teacher was saying in English class.

The data were also supported by the interview analysis result. When the respondents

were asked whether they felt worried when they did not understand every word they heard, Respondent-14 said, "Yes, because I am afraid if there is an examination and I don't understand and my score is low." Another interviewee (R9) said, "Yes, if the words I cannot understand."

When asked whether listening to short dialogues/conversations enabled them to remember what they heard easily, most of them agreed that short dialogues/conversation could help them understand the listening better. Interviewee (R7) said, "Yes, I can understand it well if it is short and clear. Another interviewee (R11) said, "Yes, it can help me." The respondents' confessions confirmed Brantmeier's (2005) study pointing out that students have low anxiety in listening skill.

To sum up, it is obvious that the majority of the respondents were worried much on the speaking skill compared to other language skills. The result also indicates that the many students were not confident in speaking resulting in a poor speaking performance. Therefore, the English teachers are highly suggested to put it into account and find out effective ways to reduce the anxiety that the students experience during their learning of language, especially of speaking skill as well as other language skills to enhance successful language learning in the context of English as a foreign language.

\section{Conclusion and Suggestion}

The results of the study have shown the most dominant senior high school students' anxiety of language skills was speaking, followed by Reading, Writing, and Listening. The result also implies that the speaking problem may occur due to the lack of various task teachers have assigned to the students dealing with the language skills. Moreover, teachers are also suggested to be more creative in their teaching and learning activities, focusing more on the student centered learning.

In addition, to reduce the magnitude of anxiety in language learning, it is highly suggested that teachers provide more fun and joyful teaching and learning activities. By so-doing the students can minimize their anxiety and lead to a better achievement in their study. In order to be better and develop more, a big scale study should be kept on doing for future research. 


\section{References}

Aida, Y. (1994). Examination of Horowitz, Horowitz, and Cope ${ }^{e e}$ construct of foreign language anxiety: The case of students of Japanese. Modern Language Journal, 78(2), 155-68.

Akkoyunlu, B., \& Soylu, M. Y. (2008). A study of student's perceptions in a blended learning environment based on different learning style. Educational Technology \& Society, I(11), 183-193.

Anandari, C. L. (2015). Indonesian EFL students' anxiety in speech production: Possible causes and remedy. TEFLIN Journal, 26(1), 1-16.

Bailey, P., Onwuegbuzie, A. J., \& Daley, C. E. (2000). Correlates of anxiety at three stages of the foreign language learning process. Journal of Language and Social Psychology., 19(4), 474-490.

Brown, A. C. (1986). Grammar and composition. Boston: Houghton Miffin company.

Brown, D. (2001). Principles of language learning and teaching. New Jersey: Prentice-Hall, Inc.

Brown, H. D. (2000). Principles of language tearning and teaching (4th ed.). New York: Longman (Formerly New Jersey: Prentice Hall).

Brown, H. D. (2001). Teaching by principles: An interactive approach to language pedagogy. New York: Addison Wesley Longman.

Brown, H. D. (2007). Principles of language learning and teaching. New York: Pearson education, Inc.

Celce-Murcia, M. (2001). Teaching English as a second or foreign language (3rd ed.). Boston, MA: Heinle \& Heinle.

Cheng, Y. (2001). Learners' Beliefs and Second Language Anxiety Concentric. Studies in English Literature and Linguistics, 27(2), 75-90.

Cohen, A. D., Oxford, R. L., \& Chi, J. C. (2001). Learning style survey. Retrieved from http//carla.acad.umn.edu/profiles/Cohen-profile.html

Cooke, R., Bewick, B. M., Barkham, M., Bradley, M., \& Audin, K. (2006). Measuring, monitoring and managing the psychological well-being of students. British Journal of Guidance and Counseling, 34, 505-517.

Cresswell, J. W. (2003). Research design: Qualitative, quantitative, and mixed method approaches. Thousand Oaks, Calif: Sage Publication.

Dangwal, R., \& Mitra, S. (1999). Learning styles and perceptions of self. International Educational journal, I(1), 61-71. Retrieved from http://iej.cjb.net 
Downs. (2008). Listening skill training. United States of America: ASTD Perss.

Dunn, R., \& Dunn, K. (1989). Teaching secondary students through their individual learning styles. Boston: Allyn \& Bacon.

Dunn, R., Griggs, S. A., Olson, J., Gorman, B., \& Beasley, M. (1995). A meta-analytic validation of the Dunn and Dunn learning styles model. Journal of Educational Research, LXXXVIII(6), 353-362.

Flohr, S. (2006). Teaching listening and speking. Grin Verlag: Norderstedt Germany.

Ghania, A. (2012). An Analysis of some internal and external factors influencing learner's success in EFL (unpublished dissertation). Mohammed Kheidher University of Biskra.

Given, B. K. (2002). Teaching to the brain's natural learning system. Alexandria, VA: Association for Supervision and Curriculum Development.

Grasha, A. F. (1996). Teaching with style: A practical guide to enhancing learning by understanding teaching and learning styles. Pittsburgh, PA: Alliance Publishers.

Gregorc, A. F. (1979). Learning/teaching styles: Potent forces behind them. Educational Leadership, XXXVI, 234-236.

Gregorc, A. F. (1985). Inside styles: Beyond the basics. Columbia, CT: Gregorc Assoc. Inc.

Harmer, J. (2002). How to teach English. London: Longman Inc.

Harmer, J. (2003). The practice of English language teaching (3rd ed.). Harlow Essex: Pearson Education limited.

Harmer, J. (2004). How to teach writing. Harlow: Pearson Education.

Harris, D. P. (1996). Testing English as a second language. New York: Georgetown university.

Haskin, J. (2003). Decreasing Anxiety and frustration in the Spanish language classroom: Master of arts action research project. Retrieved from http://www.eric.ed.gov/ ERICWebPortal/Home.portal?_nfpb=true\&ERICExtSearch_SearchValue_0=ED474368 \&ERICjExtSearch_SearchType_0=eric_accno\&_pageLabel=RecordDetails\&objectId=09 00000b801799

Horwitz, E. K., Horwitz, M. B., \& Cope, J. (1986). Foreign language classroom anxiety. Modern Language Journal, 70(2), 125-132.

Horwitz, M. B., Horwitz, E. K., \& Cope, J. (1991). Foreign language classroom anxiety. In E. K. Horwitz, \& D. J. Young, Language anxiety: From theory and research to classroom implications (pp. 27-39). Englewood Cliffs, NJ: Prentice Hall. 
Jones, C., Reichard, C., \& Mokhtari, K. (2003). Are students' learning styles discipline specific? Community College Journal of Research and Practice, XXVII(5), 363-375.

Kachru, B. (1992). World Englishes: approaches, issues and resources. Language Teaching, 15, 1-14.

Karthigeyan, K., \& Nirmala, K. (2013). Learning style preference of English language learners. Educationia Confab, II(1), 134-140.

Klingner, J. K., Vaughn, S., \& Boardman, A. (2007). Teaching reading comprehension to students with learning difficulties. New York: The Guilford Press.

Kolb, D. A. (1984). Experiential learning: Experience as the source of. Englewood Cliffs, NJ: Prentice-Hall.

MacIntyre, P. D., \& Gardner, R. C. (1991a). Anxiety and second language learning: Towards a theoretical clarification. In E. K. Horwitz, \& D. J. Young, Language anxiety: From theory and research to classroom implications (pp. 41-54). Englewood Cliffs, New Jersey: Prentice Hall.

MacIntyre, P. D., \& Gardner, R. C. (199b). Language anxiety: Its relationship to other anxieties and to processing in native and second languages . Language Learning, 513-534.

Matthews, D. (1996). An investigation of learning styles and perceived academic achievement for high school students. Clearing House, LXIX(4), 249-255.

Montgomery, S. (1996). Addressing diverse learning styles through the use of multimedia. Michigan: University of Michigan.

Moreillon, J. (2007). Collaborative strategies for teaching reading comprehension: Maximizing your impact. Chicago: American Library Association.

Muhaisen, M. S., \& Al-Haq, F. A.-A. (2012). An investigation of the relationship between anxiety and foreign language learning among 2nd secondary students in second Amman directorate of education. International Journal of Humanities and Social Science, 2(6), 226-240.

Myers, P. B., \& Myers, I. (1995). Gifts differing: Understanding personality types. Oxford: Oxford University Press.

Nunan, D. (2003). Practical English language teaching. New York: McGraw-Hill Publising Co.

Oxford, R. (1990). Language learning strategies: What every teacher should know. Boston: Heinle\& Heinle.

Pritchard, A. (2009). Ways of learning. Rouledge. 
Reid, J. M. (1995). (Ed.) Learning styles in the ESL/EFL classroom. Boston: Heinle \& Heinle.

Richards, J. C. (2008). Teaching listening and speaking. New York: Cambridge University Press.

Skehan, P. (1989). Individual differences in second-language learning. London: Edward Arnold.

Tharp, R. G., \& Gallimore, R. (1988). Rousing minds to life: Teaching, learning, and school in social context. New York: Cambridge University Press.

Thornbury, S. (2005). How to teach speaking . Essex: Pearson Longman.

Worde, R. V. (1998). An investigation of students foreign language anxiety. Retrieved from (ERIC Document Reproduction Service): http://www.eric.ed.gov/ERICWebPortal

Young, D. J. (1991). Creating a low-anxiety classroom environment: What does language anxiety research suggest? Modern Language Journal, 75, 426-439.

Zapalska, A., \& Brozik, D. (2006). Learning style and online education. Emerald Group Publishing Limited, XXIII(5), 325-335. doi:10.1108/10650740610714080

Zheng, Y. (2008). Anxiety and second/foreign language learning revisited. Canadian Journal for New Scholars in Education, 1(1), 1-12. 